ORIGINAL ARTICLE

\title{
Habitat use, fruit consumption, and population density of the black-headed night monkey, Aotus nigriceps, in southeastern Peru
}

\author{
William. D. HELENBROOK ${ }^{1,2 *}$ @ , Madison L. WILKINSON³ , Jessica A. SUAREZ ${ }^{1}$ \\ Tropical Conservation Fund, Marietta, GA 30064, USA \\ 2 State University of New York, College of Environmental Science and Forestry, Syracuse, NY, USA \\ ${ }^{3}$ Colorado College, Colorado Springs, CO, USA \\ * Corresponding author: wdhelenb@syr.edu; (D) https://orcid.org/0000-0002-2706-3525
}

\begin{abstract}
The black-headed night monkey, Aotus nigriceps, has one of the largest distribution ranges of the 11 night monkey species found across Central and South America. Yet, only three studies have focused on their ecology, describing considerable variation in habitat, group composition, and population density. Therefore, we analyzed habitat use, group composition, population density, and diet of 14 groups at two field sites in southeastern Peru. All sampled groups were found in secondary tropical rainforest, often dominated by native bamboo species. Half of the observed sleeping sites were in bamboo stands, though groups also emerged from cane thickets and lianas. This contrasts with other Aotus studies which have found groups living in tree cavities and lianas. Population density estimates for both sites were 19 and 50 individuals per $\mathrm{km}^{2}$, outside the range previously reported for $A$. nigriceps (31-34 individuals per $\mathrm{km}^{2}$ ). We recovered seeds of 12 species from fecal samples over the course of two field seasons, belonging mainly to Cecropiaceae, Piperaceae and Moraceae. Our results suggest that the black-headed night monkey in Peru can survive and even thrive in secondary forest, feeding extensively on pioneer species, occupying a range of forest types, all while living near human settlements.
\end{abstract}

KEYWORDS: Amazon, primates, Aotidae, conservation, owl monkey, nocturnal, habitat

\section{Uso de habitat, consumo de frutos, y densidad poblacional del mono nocturno de cabeza negra, Aotus nigriceps, en el sureste de Perú}

\section{RESÚMEN}

El mono nocturno de cabeza negra, Aotus nigriceps, tiene uno de los rangos de distribución más grandes de las 11 especies de monos nocturnos que se encuentran en América Central y del Sur. Sin embargo, solo tres estudios se han centrado en su ecología, describiendo una variación considerable en el hábitat, la composición del grupo y la densidad poblacional. Por lo tanto, analisamos el uso de hábitat, la composición del grupo, la densidad poblacional y la dieta de 14 grupos en dos sitios de campo en el sureste de Perú. Todos los grupos muestreados se encontraron en selva tropical secundaria, a menudo dominada por especies nativas de bambú. La mitad de los dormideros observados estaban en bambú, aunque también surgieron grupos de matorrales de cańa y lianas. Esto contrasta con otros estudios, que encontraron grupos de Aotus viviendo en cavidades de árboles y lianas. Las estimaciones de densidad poblacional para los dos sitios fueron de 19 y 50 individuos por $\mathrm{km}^{2}$, fuera del rango previamente reportado para $A$. nigriceps (31-34 individuos por $\mathrm{km}^{2}$ ). Recuperamos semillas de 12 especies de muestras fecales en el transcurso de dos temporadas de campo, pertenecientes principalmente a Cecropiaceae, Piperaceae y Moraceae. Nuestros resultados sugieren que el mono nocturno de cabeza negra puede sobrevivir, e incluso prosperar, en el bosque secundario, alimentándose ampliamente de especies pioneras, ocupando una variedad de tipos de bosque, todo mientras vive a menos de $1 \mathrm{~km}$ de asentamientos humanos.

PALABRAS-CLAVE: Amazonía, primatas, Aotidae, conservación, mono nocturno, hábito nocturno 


\section{INTRODUCTION}

There are currently 11 recognized species of night monkey, Aotus Illiger 1811 (Defler and Bueno 2007; Rylands and Mittermeier 2009), though taxonomy of the genus is still disputed (Ruiz-Garcia et al. 2011). These wide-ranging nocturnal primates are found in various tropical and subtropical habitat types ranging from Panama to Argentina (previously outlined in Aquino and Encarnacion 1998). Aotus habitat varies considerably, encompassing a broad altitudinal gradient ranging from lowland rainforest to cloud forest, primary and secondary forest as described by Chokkalingam and De Jong (2001), and fragmented or selectively logged habitat. They also use lower and upper canopy, and are tolerant of seasonal rainfall and temperature variation, along with various levels of habitat disturbance, including bamboo thickets, mangroves, palm trees, and gallery forest (e.g., Wright 1994; Aquino and Encarnación 1994; Fernandez-Duque et al. 2008). Night monkey groups can also be found living near human settlements (Wright 1989; Fernandez-Duque et al. 2007).

Aotus groups may contain up to six individuals, including a monogamous pair with infant, juveniles, and one subadult. Consistent evidence of solitary behavior has also been reported in A. azarae (Huck and Fernandez-Duque 2017). They are primarily frugivorous and supplement their diet with leaves, nectar, flowers, and insects (Wright 1989; Wright 1994). Wright (1985) describes as many as 70 fruit species consumed by Aotus nigriceps (Dollman, 1909), including Moracae, Annonaceae, Leguminosae, and Sapindaceae species. Crepuscular and nocturnal behavior likely provides Aotus an opportune time for capturing a wide array of insects available at dusk and in the night (Wolovich 2010; Wright 2011). Evidence of diurnal behavior does exist in Aotus azarae (Fernandez-Duque 2003), though activity in Aotus nigriceps Dollman 1909 is reported to be minimal (Khimji and Donati 2014).
The black-headed night monkey, A. nigriceps, occurs throughout a large part of the central and upper Amazon, and yet the majority of relevant information on habitat, population density, and group size for the species are centered on three nearby sites. One study in the central-eastern Peruvian Amazon recorded 26 groups on transect survey walks (Aquino et al. 2013), another focused on a single group over the course of 65 days (Khimji and Donati 2014) and another study extensively followed two groups (Wright 1985; Wright 1994). Habitat has been described as both primary and secondary forest, seasonally flooded, terra firme, and lowland rainforest, as well as forest patches with bamboo and palm species (Wright 1985; Aquino et al. 2013; Khimji and Donati 2014). Group composition largely consists of a mating pair with an infant, a juvenile and one subadult (Wright 1994); however, Aquino et al. (2013) describe an average of 2.8 individuals per group with a maximum of 4, while Khimji and Donati (2014) followed a single pair with a subadult. A single study has reported A. nigriceps density ( 31.1 individuals per $\mathrm{km}$ ) based on the number of sightings per $10 \mathrm{~km}$ (Aquino et al. 2013). Density estimates are more widely available for other Aotus species, ranging from 3.2 to 64 individuals per $\mathrm{km}^{2}$ (e.g., Aquino and Encarnacion 1988; Fernandez et al. 2001; Svensson et al. 2010; Maldanado and Peck 2014). We therefore aimed at expanding our understanding of the ecology of $A$. nigriceps, by studying their habitat use, group size, seasonal dietary shifts, and population density two sites in Amazonian Peru.

\section{MATERIAL AND METHODS}

Field work was carried out at two sites in the Manu Biosphere Reserve in southeastern Peru: Villa Carmen Biological Station $\left(12^{\circ} 53^{\prime} 39 » \mathrm{~S}, 71^{\circ} 24>16 » \mathrm{~W}\right)$, a conservation area managed by the Asociación para la Conservación de la Cuenca Amazónica (ACCA) in the Cuzco region, and the Manú Learning Centre (MLC) $\left(12^{\circ} 47^{\prime} 22^{\prime \prime} \mathrm{S}, 71^{\circ} 23^{\prime} 32^{\prime \prime} \mathrm{W}\right)$ in the Madre de Dios region (Figure 1). Both Amazonian sites occur within
A

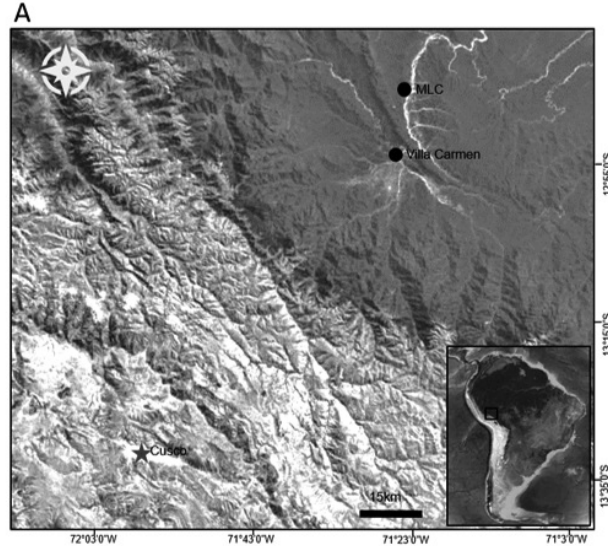

B

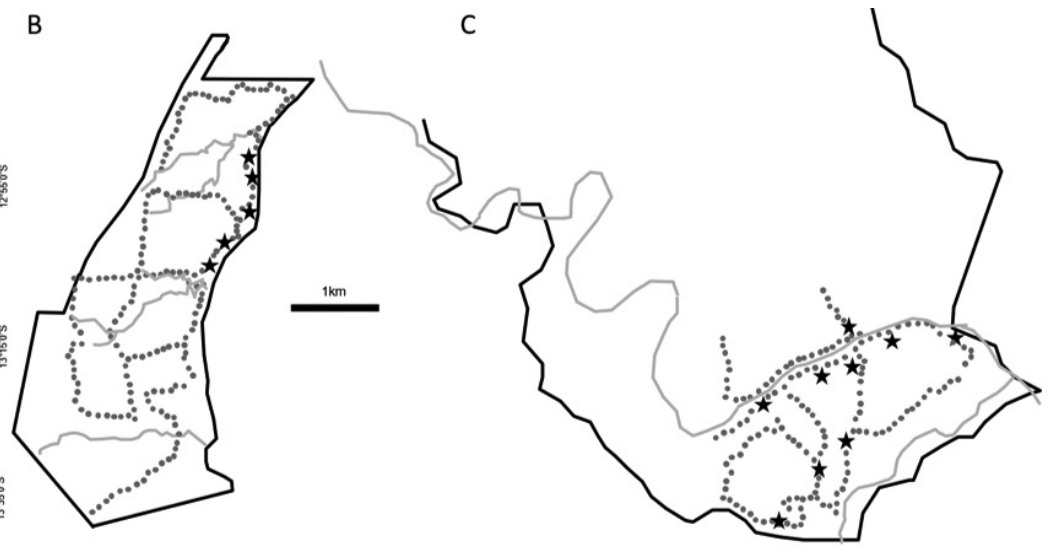

Figure 1. (A) Geographic location of the two study areas in southeastern Peru: Manu Learning Center (B) and Villa Carmen Biological Station (C). Night monkey groups (black stars) were located while conducting line transect surveys or during routine monitoring of trail systems (gray dots). 
tropical premontane forest, exhibiting similarly stable average temperatures throughout the year $\left(22^{\circ} \mathrm{C}\right.$; maximum $32^{\circ} \mathrm{C}$ and minimum $\left.10^{\circ} \mathrm{C}\right)$. Average annual rainfall ranges from 3200 $5000 \mathrm{~mm} \mathrm{yr}^{-1}$. The highest rainfall occurs from December to March and the driest months occur from May to September. Villa Carmen contains $30.65 \mathrm{~km}^{2}$ of protected primary forest within the Manu Biosphere Reserve, though our surveys were conducted almost entirely in secondary forest $(16.8 \mathrm{~km}$ of trails). MLC has a mixed history of plantations and cattle grazing, coupled with selectively logged and undisturbed, primary forest. We sampled both secondary (11 km of trails) and primary forest $(2.5 \mathrm{~km})$ at MLC. In the secondary forest, $7 \mathrm{~km}$ were in a previous timber harvest zone, 0.75 $\mathrm{km}$ in secondary bamboo forest, and $3.25 \mathrm{~km}$ in a selectively logged area.

We collected data from 14 black-headed night monkey groups during April 2016, November 2016 and April 2017 at Villa Carmen, and during April 2017 at MLC. Population density was estimated using three different methods previously applied in other Aotus studies: encounter rates per distance traveled (Pontes et al. 2012), line transects utilizing perpendicular methods using detection function models (Marhsall et al. 2008), and direct counts (Fernandez et al. 2001). In the first method, we calculated the number of groups encountered per kilometer walked. Established trails were walked from 18:00 to $21: 00 \mathrm{~h}$ at $1-2 \mathrm{~km}$ per hour, scanning vegetation continuously as a group of two to five field assistants spaced out evenly. This method was used as a baseline for comparison between our sites and earlier Aotus studies. For encounter rates and line transects, surveys followed pre-existing trails so as not to disturb habitat, which as a result sometimes included nonlinear routes. However, most trails at Villa Carmen run parallel to one another and those at MLC are largely linear (Figure 1). The closest distance between trails was $250 \mathrm{~m}$, and detection of groups was not feasible beyond $25 \mathrm{~m}$. There was little evidence of avoidance behavior as the trails are routinely walked and night monkeys have been observed near trails. Every 100-200 m, field assistants would pause and listen for calls. Once a monkey was spotted, we would observe them in order to obtain demographic information, group size, GPS location, record time, and to measure the perpendicular distance from transect to group (Marshall et al. 2008). In the second method, we calculated population density from survey data using the program DISTANCE (version 6.2). Lastly, we simply calculated the known number of groups and individuals within a well-studied area at Villa Carmen over the course of two years. We determined nesting sites during the day and confirmed general travel patterns for each group in the area both at dusk and dawn.

We later revisited the area where night monkey groups were found during transect walks to perform habitat analysis, classifying forests based on qualitative factors, i.e., secondary versus primary forest, and presence of bamboo or cane, or lianas (Ganzhorn 2003). We took canopy cover photos at each group location and used ImageJ software (1.4.3.67) to calculate canopy cover percentages. GPS points taken at each location were paired with satellite imagery to determine proximity of monkey groups to known human settlements. A quantitative estimate of forest complexity for each group was made using $50 \mathrm{~m} \times 2 \mathrm{~m}$ plots (Gentry 1982), starting $1 \mathrm{~m}$ off the trail and measuring $1 \mathrm{~m}$ beyond, for both sides from where the group was located. All woody trees $\geq 10 \mathrm{~cm}$ diameter at breast height (approximately $1.3 \mathrm{~m}$ above ground) were recorded within the plot (Ganzhorn 2003).

We collected 48 fecal samples (33 from Villa Carmen and 15 from MLC; 26 in spring and 22 in the fall) (Table 1) for a preliminary characterization of diet from identification of deposited seeds. Fecal collection was conducted by covering forest floor with plastic mesh or cloth nets below areas where night monkeys had previously been observed or where there was evidence of their feeding. The nets were used to catch any falling fecal samples and monitored daily throughout the study. The fecal samples were preserved in formalin and were later analyzed in the laboratory. We then strained samples using cheese cloth to recover seeds and then examined them under a BSZ405 stereo microscope (Boeco, Germany). Seeds were then identified to the lowest possible taxonomic level using available literature and categorized based on association with primary or secondary-forest types (e.g., Cornejo and Janovec 2010).

Table 1. Plant taxa identified from seeds recovered from Aotus nigriceps fecal samples. Values are the frequency of occurrence of seeds in recovered samples from each site and sampling occasion. VC = Villa Carmen; MLC = Manu Learning Center; $\mathrm{N}=$ fecal sample size.

\begin{tabular}{|c|c|c|c|c|}
\hline \multirow{2}{*}{ Genus (Family) } & \multirow{2}{*}{$\begin{array}{c}\text { April } \\
2016 \\
\text { VC } \\
(\mathrm{N}=11)\end{array}$} & \multirow{2}{*}{$\begin{array}{c}\text { November } \\
2016 \\
\text { VC } \\
(\mathrm{N}=22)\end{array}$} & \multicolumn{2}{|c|}{$\begin{array}{l}\text { April } \\
2017\end{array}$} \\
\hline & & & $\begin{array}{c}\mathrm{VC} \\
(\mathrm{N}=9)\end{array}$ & $\begin{array}{c}\mathrm{MLC} \\
(\mathrm{N}=6)\end{array}$ \\
\hline Philodendron Schott (Araceae) & 0 & 0 & 11.1 & 50 \\
\hline Annonaceae Juss. & 0 & 0 & 0 & 33.3 \\
\hline Aniba Aubl. (Lauraceae) & 0 & 13.6 & 0 & 0 \\
\hline Physocalymma Pohl (Lythraceae) & 54.5 & 0 & 0 & 33.3 \\
\hline Bellucia Neck. (Melastomataceae) & 27.3 & 0 & 22.2 & 16.7 \\
\hline Henriettella Naudin (Melastomataceae) & 0 & 0 & 11.1 & 33.3 \\
\hline Ficus L. (Moraceae)* & 0 & 27.3 & 55.5 & 0 \\
\hline Psidium L. (Myrtaceae) & 0 & 31.8 & 0 & 0 \\
\hline Piper L. (Piperaceae) & 45.5 & 4.5 & 66.7 & 66.7 \\
\hline Solanum L. (Solanaceae) & 0 & 0 & 0 & 16.7 \\
\hline Urera Gaudich. (Urticaceae) & 27.3 & 0 & 0 & 0 \\
\hline Cecropia Loefl (Urticaceae)* & 100 & 77.3 & 100 & 66.7 \\
\hline
\end{tabular}

*Previously described in Aotus nigriceps (Wright 1981 and Wright 1985) 


\section{RESULTS}

Nine night-monkey groups were found at Villa Carmen and five at MLC, ranging in size from two to five individuals, though a solitary individual was also encountered (Table 2 ). These groups were revisited over the course of the two years. All groups were in areas with some level of historical logging and habitat degradation (Table 2). Basal area estimates were consistent with previously described degraded habitat (Brown and Lugo 1990). All but one group at Villa Carmen was found in forest dominated by native bamboo species, Guadua weberbaueri Pilg. and Guadua sarcocarpa Londoño and P. M. Peterson. A single group was found in degraded cane (Gynerium Willd ex P. Beauv) forest with bamboo. Only two groups at MLC were found in areas with bamboo, while the others were found in secondary forests devoid of bamboo.

We were unable to locate specific nesting sites for all groups; however, of the five that were located at Villa Carmen, three were in bamboo stands, one in a cane thicket, and another in lianas. Though we could not locate an exact nesting site for the four remaining groups (44\%), we were often present when they first started moving in the evenings. For example, we could often triangulate the general area where they would begin moving at dusk but could not locate them during the day to pinpoint their sleeping site. These four groups were also found in areas dominated by bamboo. At MLC, only one nesting site was confirmed, and this was found in lianas lacking any bamboo. All groups were found within $1 \mathrm{~km}$ of each associated field station. Two groups at Villa Carmen and one group at MLC were routinely found on the perimeter of the station in secondary forest $(<100 \mathrm{~m})$.

Estimated DISTANCE densities were higher at Villa Carmen (50.0 individuals per $\mathrm{km}^{2}$ ) than at MLC (19.2 individuals per $\mathrm{km}^{2}$ ). Both estimates had a large confidence interval, ranging from 17.0-147.0 individuals per $\mathrm{km}^{2}$ at Villa Carmen, and 4.9-75.3 individuals per $\mathrm{km}^{2}$ at MLC. The known number of individuals in our sampling area at Villa Carmen was 17.5 individuals per $\mathrm{km}^{2}$ and the encounter rate was 5.8 groups per $10 \mathrm{~km}$. We could not calculate these parameters for MLC since group composition there is not as well-known as at Villa Carmen, and our sample size was too small to calculate the encounter rate.

We recovered seeds belonging to 12 genera and ten families (Table 1). The number of taxa recovered from Villa Carmen groups in bamboo forest was similar $(\mathrm{N}=10)$ to that from MLC $(\mathrm{N}=8)$. We recovered as many as seven genera from a single MLC group, and just four genera from a group living in disturbed mixed bamboo forest at Villa Carmen. Cecropia was found in all sampled groups, and three genera were found in both sampled seasons: Cecropia sp., Piper sp., and Ficus sp. Groups at MLC consumed all the same fruits identified at Villa Carmen in Spring 2016 except for Urera sp. However, we found that groups at MLC consumed two other fruit species, including an unidentified Annonaceae and Solanum sp.

\section{DISCUSSION}

All black-headed night monkey groups in our study were found in secondary forest, though there is considerable evidence to suggest that they are also found in primary habitat based on camera trap data provided by MLC (unpublished data) and from previous Aotus studies (Wright 1978; Aquino and Encarnacion 1994; Cornejo et al. 2008; Aquino et al. 2013; Shanee et al. 2013). Limited sampling in primary forest is presumably the main reason we did not encounter Aotus in these areas. Dense canopy in primary forest also likely limited our ability to detect auditory or visual cues of night monkeys.

Table 2. Habitat structure of Aotus nigriceps groups found at Villa Carmen (VC) and Manu Learning Centre (MLC) in southeastern Peru. $N$ = number of individuals in group.

\begin{tabular}{|c|c|c|c|c|c|c|c|}
\hline Field site & Group & $\mathrm{N}$ & Habitat type & Nest type & Canopy cover (\%) & Total basal area $\left(\mathrm{m}^{2} \mathrm{ha}^{-1}\right)$ & Elevation ( $m$ a.s.l.) \\
\hline VC & A & 4 & Secondary forest, bamboo & Bamboo & 74.7 & 12.66 & 530 \\
\hline VC & B & 3 & Secondary forest, bamboo & Bamboo & 76.9 & 11.91 & 530 \\
\hline VC & C & 3 & Secondary forest, bamboo & Unknown & 65.5 & 2.11 & 610 \\
\hline VC & D & 2 & Secondary forest, bamboo & Bamboo & 69.3 & 10.34 & 529 \\
\hline VC & $E$ & 3 & Secondary forest, cane & Cane & 68.3 & 22.1 & 516 \\
\hline VC & $\mathrm{F}$ & 3 & Secondary forest, Bamboo & Liana & 69.8 & 9.93 & 529 \\
\hline VC & G & 3 & Secondary forest, Bamboo & Unknown & 70.2 & 14.15 & 530 \\
\hline VC & $\mathrm{H}$ & 3 & Secondary forest, Bamboo & Unknown & 68.2 & 4.85 & 529 \\
\hline VC & I & $2^{*}$ & Secondary forest, Bamboo & Unknown & 72.3 & 19.75 & 529 \\
\hline MLC & $\mathrm{T} 2 \mathrm{~A}$ & 5 & Secondary forest & Unknown & 80.8 & 15.62 & 516 \\
\hline MLC & $\mathrm{T} 2 \mathrm{~B}$ & 4 & Secondary forest & Liana & 71.3 & 14.11 & 512 \\
\hline MLC & T9A & 3 & Secondary forest & Unknown & 84.4 & 13.11 & 489 \\
\hline MLC & T9B & $2^{*}$ & Secondary forest, Bamboo & Unknown & 77.2 & 38.12 & 487 \\
\hline MLC & Camp & 4 & Secondary forest, Bamboo & Unknown & 76.0 & NA & 456 \\
\hline
\end{tabular}

*In two cases, groups were observed but exact numbers could not be ascertained. We include the minimum number of individuals observed (N), though the total group size could be higher. The qualitative assessment was based on visual assessment and unpublished historical records provided by each field station. In a single case, basal area was not available (NA). 
The majority of groups were found in forest dominated by native bamboo, and all groups were found in proximity to each field station $(<1 \mathrm{~km})$. Our results suggest that night monkeys are likely to be found, and even potentially thrive, in these types of secondary forest dominated by bamboo and cane species. Aotus nigriceps were also found to attain relatively high densities (31.1 individuals per $\mathrm{km}^{2}$ ) living in mixed bamboo forests in an area $-150 \mathrm{~km}$ northeast from our study sites, suggesting that this species may be able to survive in an array of forest types (Aquino et al. 2013).

Estimated population density and encounter rates at Villa Carmen were both higher than the only other $A$. nigriceps report (Aquino et al. 2013); however, the known number of individuals per square kilometer was actually lower. MLC density estimates were similar to encounter rates found at Villa Carmen. A number of factors could contribute to differences in density estimates, most notably habitat type. Aquino et al. (2013) pooled results from three habitat types so we are unable to ascertain whether there was a significant difference compared to our study. However, they found primary forest and semi-dense primary forest with some bamboo had a higher percentage of sightings compared to open primary forest with bamboo. Considering most of our sampled area was secondary forest with bamboo, it is therefore difficult to make a reasonable comparison (Nelson 1994). Svensson et al. (2010) also surveyed three different types of Aotus zonalis habitat in Panama. To our knowledge, none of these contained bamboo but still had similar densities compared to our study (i.e., 0- 19.7 individuals per $\mathrm{km}^{2}$; mean $=13.2$ ).

Our DISTANCE estimate at Villa Carmen was higher than the known number of individuals; however, the confidence interval was fairly large, likely due to a relatively small sample size. It is conceivable that we counted some groups twice on trails that were only $250 \mathrm{~m}$ apart, since night monkeys have been reported to travel as far as $708 \mathrm{~m}$ in 24 hours (Wright 1989). However, duplicate sampling is not likely since we established sleeping sites in most cases, and monitored travel patterns for each group.

Night monkeys have been reported to use tree holes or vine tangles as nesting sites, which are normally restrictive as they limit their ability to travel particularly far since they need to return to the same site the following morning (Aquino and Encarnacion 1986; Fernandez-Duque et al. 2008). However, night monkeys at Villa Carmen routinely returned to the same bamboo patches despite there being other dense patches all around and no competing groups vying for sleeping sites. There was no evidence that they used tree holes, and we only observed two nesting sites composed of tangled vines. The absence of nesting sites in tree holes may be related to the scarcity of such resource in the secondary forest. Additionally, the return to the same sleeping sites in consecutive days may be explained by the familiarity in established routes and accessibility to food sources.

Diet analysis of defecated seeds showed that Aotus relied heavily on Cecropia spp. However, no species dominated sample composition. Consumption of Cecropia spp. might have little to do with preference, but rather with the availability of this species in secondary forests. Most groups did not have access to primary habitat, though they could have traveled to nearby areas with reduced habitat degradation. Two of our sampled groups also made use of abandoned guava (Psidium) orchards as part of their home range, areas frequented by workers at the field station during the day. There was no evidence that other sympatric diurnal primates used these guava orchards during the day, which makes them potentially valuable food sources to the night monkeys. Psidium seeds were recovered from one of these nearby groups along with two others which were not in proximity to these orchards.

In total, we recovered twelve seed types from fecal samples, and only two of these genera were previously described in Aotus (Table 1: Wright 1981 and Wright 1985). No other known studies have reported on fruits consumed in other Aotus species. Given our small sample size, the diversity of fruits consumed is likely much larger, though Wright (1978) similarly described the use of just nine fruiting tree species by a group over the course of one month. Of course, analysis of fecal samples limits our results to seeds that remain recognizable after passing the digestive tract and does not give a full picture of other types of food consumed, such as leaves, nectar, flowers, and insects (Wright 1985; Wright 1989; Wright 1994).

The black-headed night monkey - and likely other Aotus species - are quite adaptable based on their use of degraded habitat, an omnivorous diet including the consumption of several pioneer species, and an ability to persist in areas close to human settlements. For example, there are nine other monkey species in nearby primary habitat at Villa Carmen; however, only $A$. nigriceps and Sapajus apella (Linnaeus 1758) were found in the sampled secondary forest with bamboo, an area which also has evidence of hunting based on camera trap footage (unpublished data). Likewise, night monkeys use multiple habitat types and forests with varying levels of degradation which suggests that they can traverse ecological matrices that might be difficult for other species. Their consumption of fruit from a dozen tree species suggests that they may be able to disperse an array of seeds throughout the year, though over short distances, as their ability to move seeds over large distances is presumably limited. We previously conducted a limited analysis of seed germination success and time to germination in Aotus nigriceps and found both measurements were positively associated with digestion (unpublished data). However, expanded sampling is necessary 
to determine to what degree night monkeys contribute to seed dispersal, predation, and germination success.

\section{CONCLUSIONS}

We report that Aotus nigriceps is able to occupy degraded habitat, inhabiting bamboo forests and relying on a varied diet of fruits from pioneer species. The presence of this species in heavily disturbed habitat suggests some level of behavioral and dietary plasticity. Expanded sampling into more diverse habitat types and across a larger geographical range would likely contribute to our understanding of their ecological niche.

\section{ACKNOWLEDGMENTS}

We would like to thank Asociación para la Conservación de la Cuenca Amazónica, and staff at both the Villa Carmen Biological Station and Manu Learning Centre (CREES) for hosting us, clearing trails, and providing valuable insight into location and behavior of groups. We are indebted to the students and staff from The School for Field Studies (Peru) who assisted with data collection and logistics, specifically Isabelle Berman, Noah Linck, Audrey Nelson, Ben Sharaf, Caroline Rzucidlo, Katlin Gott, Leigh Preston, and Sheridan Plummer. Special thanks to Brooke Zale and two anonymous reviewers for their valuable feedback on the manuscript. Logistical support provided by the Tropical Conservation Fund.

\section{REFERENCES}

Arroyo-Rodriguez, V.; Andersen, E.; Bravo, S.P.; Stevenson, P.R. 2015. Seed dispersal by howler monkeys: current knowledge, conservation implications, and future directions. In: Kowalewski, M.M.; Cortez-Ortiz, L.; Youlatos, D.; Garber, P.A.; Urbani, B. (Ed.). Howler monkeys: Behavior, Ecology, and Conservation. Springer, New York, p.111-139.

Aquino, R.; Encarnación, F. 1986. Characteristics and use of sleeping sites in Aotus (Cebidae: Primates) in the Amazon lowlands of Peru. American Journal of Primatology, 11: 319-331.

Aquino, R.; Encarnación, F. 1988. Population densities and geographic distribution of night monkeys (Aotus nancymai and Aotus vociferans) (Cebidae: Primates) in northeastern Peru. American Journal of Primatology, 14: 375-381.

Aquino, R.; Encarnacion, F. 1994. Owl monkey populations in Latin America: field work and conservation. In: Baer, J. F.; Weller, R. E.; Kakoma, I. (Ed). Aotus: The owl monkey. Academic Press, San Diego, p.59-95.

Aquino, R.; Cornejo, F.M.; Heymann, E.W. 2013. Primate abundance and habitat preference on the lower Urubamba and Tabo rivers, central-eastern Peruvian Amazonia. Primates, 54: 377-383.

Benítez-Malvido, J.; González-Di Pierro, A.M.; Lombera, R.; Guillén, S.; Estrada, A. 2014. Seed source, seed traits, and frugivore habits: Implications for dispersal quality of two sympatric primates. American Journal of Botany, 101: 970-978.
Brown, S.; Lugo, A.E. 1990. Tropical secondary forests. Journal of Tropical Ecology, 6: 1-32.

Chokkalingam, U.; De Jong, W. 2001. Secondary forest: a working definition and typology. The International Forestry Review, 3: 19-26.

Cornejo, F.M.; Aquino, R.; Jimenez, C. 2008. Notes on the natural history, distribution and conservation status of the Andean night monkey, Aotus miconax Thomas, 1927. Primate Conservation, 23: $1-5$.

Cornejo, F.; Janovec, J. 2010. Seeds of Amazonian plants. Princeton University Press, Princeton, 155p.

de Marques, A.A.; Rylands, A.B.; Schneider, M. 2008. Seed dispersal and germination by the brown howler monkey (Alouatta guariba clamitans Cabrera, 1940) in an area of Atlantic Forest in Southern Brazil. In: Ferrari, S.F.; Rímoli, J. (Ed.). A Primatologia no Brasil. Sociedade Brasileira de Primatologia, Biologia Geral e Experimental, Porto Alegre, p.109-113.

Defler, T.R.; Bueno, M.L. 2007. Aotus diversity and the species problem. Primate Conservation, 22: 55-70.

Fernandez-Duque, E.; Rotundo, M.; Sloan, C. 2001. Density and population structure of owl monkeys (Aotus azarai) in the Argentinean Chaco. American Journal of Primatology, 53: 99-108.

Fernandez-Duque, E. 2003. Influences of moonlight, ambient temperature, and food availability on the diurnal and nocturnal activity of owl monkeys (Aotus azarae). Behavioral Ecology and Sociobiology, 54: 431-440.

Fernandez-Duque, E.; Fiore, A.; Carillo, G. 2008. Behavior, ecology, and demography of Aotus vociferans in Yasuni National Park, Ecuador. International Journal of Primatology, 29: 421-431.

Fuzessy, L.F.; Cornelissen, T.G.; Janson, C.; Silveira, F.A. 2016. How do primates affect seed germination? A meta-analysis of gut passage effects on neotropical plants. Oikos, 125: 1069-1080.

Ganzhorn, J.U. 2003. Habitat description and phenology. In: Setchell, J.M.; Curtis, D.J. (Ed.). Field and laboratory methods in primatology, Cambridge University Press, Cambridge, p.40-56.

Garber, P.A. 1986. The ecology of seed dispersal in two species of callitrichid primates (Saguinus mystax and Saguinus fuscicollis). American Journal of Primatology, 10: 155-170.

Hershkovitz, P. 1983. Two new species of night monkeys, genus Aotus (Cebidae, Platyrrhini): a preliminary report on Aotus taxonomy. American Journal of Primatology, 4: 209-243.

Huck, M.; Fernandez-Duque, E. 2017. The floater's dilemma: use of space by wild solitary Azara's owl monkeys, Aotus azarae, in relation to group ranges. Animal Behaviour, 127: 33-41.

Janson, C.H.; Emmons, L.H. 1990. Ecological structure of the nonflying mammal community at Cocha Cashu biological station, Manu National Park, Peru. In: Gentry, A.J. (Ed.). Four neotropical rainforests. Yale University Press, New Haven, p.314-338.

Khimji, S.N.; Donati, G. 2014. Are rainforest owl monkeys cathemeral? Diurnal activity of black-headed owl monkeys, Aotus nigriceps, at Manu Biosphere Reserve, Peru. Primates, 55: 19-24.

Londono, X.; Peterson, P.M. 1991. Guadua sarcocarpa (Poaceae: Bambuseae), a new species of Amazonian bamboo with fleshy fruits. Systematic Botany, 16: 630-638. 
Maldonado-López, S.; Maldonado-Lopez, Y.; Ch, A.G.T.; CuevasReyes, P.; Stoner, K.E. 2014. Patterns of infection by intestinal parasites in sympatric howler monkey (Alouatta palliata) and spider monkey (Ateles geoffroyi) populations in a tropical dry forest in Costa Rica. Primates, 55: 383-392.

Marshall, A.R.; Lovett, J.C.; White, P.C. 2008. Selection of linetransect methods for estimating the density of group-living animals: lessons from the primates. American Journal of Primatology, 70: 452-462.

Nelson, B.W. 1994. Natural forest disturbance and change in the Brazilian Amazon. Remote Sensing Reviews, 10: 105-125.

Nuñez-Iturri, G.; Howe, H.F. 2007. Bushmeat and the fate of trees with seeds dispersed by large primates in a lowland rain forest in western Amazonia. Biotropica, 39: 348-354.

Robinson, J.G.; Redford, K.H. 1986. Body size, diet, and population density of Neotropical forest mammals. The American Naturalist, 128: 665-680.

Ruiz-García, M.; Vásquez, C.; Camargo, E.; Leguizamon, N.; Galvez, H.; Vallejo, A.; et al. 2011. Molecular phylogenetics of Aotus (Platyrrhini, Cebidae). International Journal of Primatology, 32: 1218-1241.

Rylands, A.B.; Mittermeier, R.A. 2009. The diversity of the New World primates (Platyrrhini): an annotated taxonomy. In: Garber et al. (Ed.). South American primates, Springer, New York, p.23-54.

Pilger, R. 1905. Guadua weberbaueri. Repertorium specierum novarum regni vegetabilis, 1: 152.

Pontes, A.R.; de Paula, M.D.; Magnusson, W.E. 2012. Low primate diversity and abundance in Northern Amazonia and its implications for conservation. Biotropica, 44: 834-839.

Shanee, S.; Allgas, N.; Shanee, N. 2013. Preliminary observations on the behavior and ecology of the Peruvian night monkey (Aotus miconax: Primates) in a remnant cloud forest patch, north eastern Peru. Tropical Conservation Science, 6: 138-148.

Stevenson, P.R.; Castellanos, M.C.; Pizarro, J.C.; Garavito, M. 2002. Effects of seed dispersal by three ateline monkey species on seed germination at Tinigua National Park, Colombia. International Journal of Primatology, 23: 1187-1204.

Stoner, K.E.; Riba-Hernández, P.; Vulinec, K.; Lambert, J.E. 2007. The role of mammals in creating and modifying seedshadows in tropical forests and some possible consequences of their elimination. Biotropica, 39: 316-327.

Svensson, M.S.; Samudio, R.; Bearder, S.K.; Nekaris, K.A.I. 2010. Density estimates of Panamanian owl monkeys (Aotus zonalis) in three habitat types. American Journal of Primatology, 72: 187-192.

Terborgh, J.; Nuñez-Iturri, G.; Pitman, N.C.; Valverde, F.H.; Alvarez, P.; Swamy, V.; Pringle, E. G.; Paine, C.E. 2008. Tree recruitment in an empty forest. Ecology, 89: 1757-1768.

Wehncke, E.; Dalling, J. 2005. Post dispersal seed removal and germination selected tree species dispersed by Cebus capucinus and Barro Colorado Island, Panama. Biotropica, 37: 73-80.

Wolovich, C.K.; Rivera, J.; Evans, S. 2010. Insect-foraging in captive owl monkeys (Aotus nancymaae). Folia Primatologica, 81: 63-72.

Wright, P.C. 1978. Home range, activity pattern, and agonistic encounters of a group of night monkeys (Aotus trivirgatus) in Peru. Folia Primatologica, 29: 43-55.

Wright, P. 1989. The nocturnal primate niche in the new world. Journal of Human Evolution, 18: 635-658.

Wright, P.C. 1994. The behavior and ecology of the owl monkey. In: Baer, J.F.; Weller, R.E.; Kakoma, I. (Ed.). Aotus: The owl monkey. Academic Press, San Diego. p.97-112.

Wright, P.C. 2011. The neotropical primate adaptation to nocturnality: feeding in the night (Aotus nigriceps and A. azarae). In: Norconk, M.; Rosenberger, A.L.; Garber, P.A. (Ed.). Adaptive Radiations of Neotropical Primates. Plenum Press, New York. p.369-382.

Wunderle Jr., J.M. 1997. The role of animal seed dispersal in accelerating native forest regeneration on degraded tropical lands. Forest Ecology and Management, 99: 223-235.
RECEIVED: $16 / 01 / 2019$
ACCEPTED: 28/08/2019
ASSOCIATE EDITOR: Paulo D. Bobrowiec 